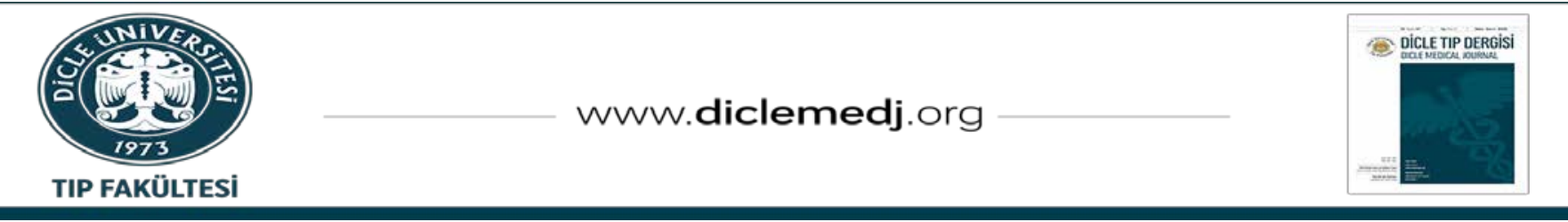

Özgün Araştırma / Original Article

\title{
Carvacrol'un Ratlarda Böbrek İskemi Reperüzyon Hasarı Üzerine Koruyucu Etkileri
}

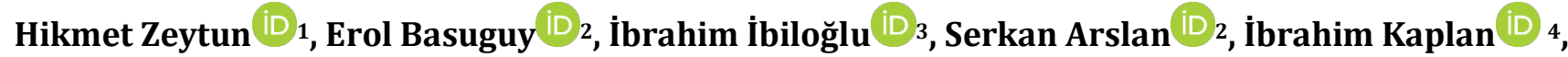 \\ M. Hanifi Okur ${ }^{i}{ }_{2}$ \\ 1 Gaziantep Üniversitesi Tıp Fakültesi Çocuk Cerrahisi AD., 27100, Gaziantep, Türkiye
}

2 Dicle Üniversitesi Tıp Fakültesi Çocuk Cerrahisi AD., 21280, Diyarbakır, Türkiye

3 Dicle Üniversitesi Tıp Fakültesi Patoloji AD., 21280, Diyarbakır, Türkiye

4 Dicle Üniversitesi Tıp Fakültesi Biokimya AD., 21280, Diyarbakır, Türkiye

Geliş: 15.07.2020; Revizyon: 25.08.2020; Kabul Tarihi: 30.08.2020

Öz

Amaç: Ratlarda böbrek iskemi reperfüzyonu hasarı üzerine Carvacrol (CARV) 'ün koruyucu etkilerini araştırmaktır.

Yöntemler: Ağırlıkları 200-250 gr arasında değișen, 30 adet erkek Wistar Albino ratlar rastgele grublara ayrıldı. 50 mg/kg ketamin ve 3mg/ kg ksilazin (periton içi) ile anestezi sağlandı. Renal arter trombozunu önlemek için 100 İU/kg heparin (periton içi) uygulamasından sonra orta hat kesi ile tüm ratlara sağ nefrektomi yapıldı. Grup I (Sham): Sağ nefrektomiyi takiben 6 saat sonra sol nefrektomi yapıldı. Grup II (I/R): Sağ nefrektomiyi takiben sol böbrek, 60 dakika iskemi ve 6 saat reperfüzyonda bırakıldı. Grup III(I/R+CARV): Grup II de uygulanan işleme ek olarak, iskemi ve reperfüzyondan hemen önce toplam $2 \mathrm{kez} 35 \mathrm{mg} / \mathrm{kg}$ periton içine Carvacrol verildi. Altı saatlik reperfüzyonu takiben ratların tamamı kardiak ponksiyonla yüksek miktarda kan alınarak sakrifiye edildi ve sol nefrektomi yapıldı. Alınan serum ve dokulardaki proiflamatuar sitokinler, oksidatif stres parametreleri çalışıldı ve histopatolojik inceleme yapılarak gruplar arasında karşılaştırma yapıldı.

Bulgular: Böbrek fonksiyon göstergesi olan Serum BUN ve kreatinin düzeyleri, I/R grubunda Sham grubuna klyasla yükselmiş ve iskeminin gerçekleştiğini göstermektedir $(\mathrm{p}<0.05)$. Aynı șekilde I/R grubunda serumda proinflamatuar sitokinlerden IL-6 ve TNF- $\alpha$ ile oksidatif stresin göstergesi olan MDA ve TOS düzeyindeki artış ve anti-inflamatuar sitokin olan IL-10 seviyesinde düşüş istatistiksel olarak anlamlı bulundu(p<0.05). IR ile IR+CARV grupları karşılaștırıldığında IL-1 $\beta$, IL-6 ve TNF- $\alpha$ değerlerinin Carvacrol verilen grupta düştüğü ve istatistiksel olarak anlamlı olduğu görüldü(p<0.05). Yine lipid peroksidasyonunun bir ürünü olan MDA'da düşüş izlendi $(\mathrm{p}<0.05)$.

Histokimyasal ölçümlerde IL-1 $\beta$, IL-6, TNF- $\alpha$, MDA ve TOS değerlerinin sham grubuna kıyasla I/R grubunda da yükseldiği ve sonuçların istatistiksel olarak anlamlı olduğu görüldü $(\mathrm{p}<0.05)$. Aynı parametrelerde $\mathrm{I} / \mathrm{R}+\mathrm{CARV}$ grubunda $\mathrm{I} / \mathrm{R}$ grubuna göre düşüş, istatistiksel olarak anlamlı bulundu(p<0.05).Bununla birlikte antiinflamatur sitokin olan IL-10`un I/R+CARV grubunda I/R grubuna göre anlamlı derecede yüksek olduğu tespit edildi.: Histopatolojik incelemede I/R grubunda iskemiye bağlı olarak böbrek tübüllerinde vakuolizasyon ve yer yer nükleus kayıpları olduğu görüldü. $\mathrm{I} / \mathrm{R}+\mathrm{CARV}$ grubunda ise tubüllerde görülen vakuolizasyonun kaybolduğu tespit edildi.

Sonuç: Carvacrolun, renal I/R ile indüklenen renal hasar üzerine olumlu etkiye sahip olduğu görülmektedir. Bu etkide ilacın antiinflamatuar özelliğinin ön planda olduğu düşünülmektedir. Bununla birlikte antioksidan parametreler üzerinde de olumlu etkiler göstermesine rağmen, süre ve doz bağımlı etkilerinin ortaya konulması için daha kapsamlı çalışmalara ihtiyaç duyulmaktadır.

Anahtar kelimeler: Börek, İskemi, Reperfüzyon, Carvacrol Rat.

DOI: 10.5798/dicletip.800278

Correspondence / Yazışma Adresi: Hikmet Zeytun, Gaziantep Üniversitesi Tıp Fakültesi Çocuk Cerrahisi AD., 27100, Gaziantep, Türkiye e-mail: hzeytun333@gmail.com 


\title{
Protective Effects of Carvacrol on Renal Ischemia Reperfusion Damage in Rat
}

\begin{abstract}
Objective: The aim of this study was to investigate the protective effect of Carvacrol (CARV) on renal ischemia reperfusion (I/R) injury in rats.

Method: 30 male Wistar Albino rats weighing 200-250 gr were divided into random groups. Anesthesia was achieved with $50 \mathrm{mg} / \mathrm{kg}$ ketamine and 3 $\mathrm{mg} / \mathrm{kg}$ xylazine (intraperitoneal). Right nephrectomy was performed to all rats by midline incision after $100 \mathrm{IU} / \mathrm{kg}$ heparin (intraperitoneal) application to prevent renal artery thrombosis. Subsequently, the left renal artery was clamped, created ischemia for 60 minutes. Group I (Sham): Left nephrectomy was performed six hours after right nephrectomy. Group II (I/R): Following right nephrectomy, left kidney was left for 60 minutes for ischemia and 6 hours for reperfusion. Group III (I/R+CARV): In addition to the procedure performed in group II, Carvacrol was given 2 times $35 \mathrm{mg} / \mathrm{kg}$ intraperitoneally just before ischemia and reperfusion. After six hours of reperfusion, all rats were sacrificed by cardiac puncture with a high volume of blood and left nephrectomy was performed. The parameters of oxidative stress and proinflammatory cytokines in the serum and tissues were analyzed and histopathological examination was performed to compare the groups.
\end{abstract}

Results: Serum BUN and creatinine levels, which are indicators of kidney function, increased in Group II compared to Group I, which shows that ischemia occurred. $(\mathrm{p}<0.05)$. Likewise, it was seen that the increase in IL-6 and TNF- $\alpha$, which are proinflammatory cytokines, and MDA and TOS levels, which are indicators of oxidative stress, were statistically significant in serum biochemical analysis. However, the decrease in IL-10 which are antiinflammatory cytokine, was also statistically significant $(\mathrm{p}<0.05)$. When IR and IR+CARV groups were compared, it was seen that IL-1 $\beta$, IL- 6 and TNF$\alpha$ values decreased and statistically significant in the group given $(\mathrm{p}<0.05)$. Again, a decrease in MDA, which is a product of lipid peroxidation, was observed $(\mathrm{p}<0.05)$.

In histochemical measurements, IL-1 $\beta$, IL-6, TNF- $\alpha$, MDA and TOS values were also increased in the I/R group compared to the sham group and the results were statistically significant $(\mathrm{p}<0.05)$. In the same parameters, decrease in I/R+CARV group compared to I/R group was found statistically significant $(\mathrm{p}<0.05)$. However, it was found that the anti-inflammatory cytokine IL-10 was significantly higher in the I/R+CARV group compared to the I/R group $(\mathrm{p}<0.05)$.

Histopathological examination revealed vacuolization and nucleus losses in kidney tubules due to ischemia in the I/R group. In the I/R+CARV group, it was found that vacuolization disappeared in the tubules.

Conclusion: Carvacrol appears to have a positive effect on renal damage induced by renal I/R. in rats. It is thought that the anti-inflammatory properties of the drug may be at the forefront in this effect. However, although it also has positive effects on antioxidant parameters, more comprehensive studies are needed to reveal time and dose dependent effects.

Keywords: Kidney, Ischemia, Reperfusion, Carvacrol, Rat.

\section{GíRiş}

Akut böbrek hasarı (ABH), özellikle yoğun bakım hastalarında sıkça karşılaşılan yüksek morbidite ve mortaliteye yol açan bir sağlık sorunudur. Özellikle sepsis ve multiorgan yetmezliği olan hastalarda daha yüksek olmakla birlikte, yoğun bakım hastalarının \%5-10'unda görülmektedir1,2. Böbrek transplantasyonu, parsiyel nefrektomi ve ürolojik girişimler ile şok, travma, sepsis gibi durumlarda geçici olarak renal kan akımının durmasıyla ortaya çıkan iskemi ve kan akımının tekrar sağlanması gerçekleşen reperfüzyon, iskemi reperfüzyon hasarında (IRH) rol oynayan en önemli mekanizmalardandır ${ }^{3}$. Özellikle renal transplantasyon hastalarında yaşanan iskemi reperfüzyon (I/R), greft disfonksiyonu ve rejeksiyonundan ölüme kadar sonuçlanan ciddi komplikasyonlara yola açabilmektedir ${ }^{4}$. Renal IRH'da, iskemi sırasında oluşan oksidatif stres ve inflamatuar yanıt ile reperfüzyon sırasında ortaya çıkan süperoksid radikalleri (SOR) önemli rol oynamaktadır. Ayrıca I/R sonucu ortaya çıan apopitozis, böbrek destrüksiyonunun derecesini belirleyen önemli parametrelerden birisidir5. Renal I/R sonucu oluşan ABH azaltmak için antioksidan, antiinflamatuar ilaç ve hormonlarla birçok çalışma yapılmış ancak bunların klinik kullanılabilirliği ile ilgili yeterli kanıt ortaya konulamamıştır $3,6-8$. Bu proplemi çözmek üzerine hala çeşitli çalışmalar yapılmaya devam edilmektedir.

Carvacrol(CARV), anti-inflamatuar, antioksidan, anti-tümöral ve antimikrobial birçok etkiye sahip oldugu bildirilen, kekik gibi aromatik bitkilerde bulunan, uçucu, esansiyel bir yağ olan monoterpetik bir fenol bileşiğidir ${ }^{3,9}$.

$\mathrm{Bu}$ çalışmayla ratlarda tek taraflı renal I/R ile indüklenen IRH üzerine CARV'un, renal 
fonksiyon, inflamatuar yanıt, oksidatif durum ve histopatolojik değişikler üzerine etkilerini ortaya konulması hedeflenmiştir.

\section{YÖNTEMLER}

Dicle Üniversitesi Hayvan Deneyleri Yerel Etik Kurulu onayı (13.05.2014/3) alındıktan sonra, ağırlıkları 200-250 gr arasında değissen, 30 adet erkek Wistar Albino ratlar rastgele 3 gruba ayrıldı. Tüm deney prosedürleri, rutin hayvan bakım kurallarına ve Laboratuvar Hayvanlarının Bakımı ve Kullanımı Kılavuzu'na (1996) uygun bir şekilde gerçekleştirildi. Ratlar, 12 saat aydınlık / karanlık döngüsü ve $\% 60 \pm 5$ nem ile kontrollü bir sicaklıkta $\left(24 \pm 1^{\circ} \mathrm{C}\right)$ kafeslerde muhafaza edildi ve standart laboratuar diyeti, su ad-libitum ile sağlandı. İşlemden 6 saat önce beslenmeleri kesildi. Anestezi için $50 \mathrm{mg} / \mathrm{kg}$ ketamin hidroklorid (Ketalar®; Pfizer,Istanbul, Turkey) ve $3 \mathrm{mg} / \mathrm{kg}$ ksilazin hidroklorid(Rompon $®$; Bayer, Istanbul, Turkey) intramusküler uygulandı. Renal arter trombozunu engellemek için $100 \mathrm{IUU} / \mathrm{kg}$ heparin (periton içi) uygulamasından sonra orta hat kesi ile sağ nefrektomi yapıldı. Grup I (Sham) $(\mathrm{n}=10)$ : Sağ nefrektomi takiben iskemi oluşturulmadan karın kapatılıp 6 saat sonra yine anestezi altında tekrar açılarak sol nefrektomi yapıldı. Grup II (I/R) (n=10): Sağ nefrektomiyi takiben sol böbrek arteri nontravmatik vasküler mini klemp ile klemplenerek 60 dakika iskemi oluşturuldu. Akabinde klemp açıldı ve 6 saat reperfüzyonda birakıldı.

Grup III(IR+CARV)( $\mathrm{n}=10)$ :Grup II'te yapılan işleme ek olarak iskemi ve reperfüzyondan hemen önce iki doz 35mg/kg CARV(Sigma-Aldirich; Merck, Germany) intraperitoneal uygulandı. Altı saatlik reperfüzyonu takiben yine anestezi altında biyokimyasal inceleme için kardiak ponksiyon ile yüksek miktarda kan alınıp ratlar sakrifiye edildi. Akabinde histokimyasal ve histopatolojik inceleme için sol nefrektomi yapıldı. Alınan böbreklerin bir kısmı histopatolojik inceleme için \% 10 formaldehid solüsyon ile sabitlenmiş, diğer kısmı doku histokimyasal inceleme için - $80^{\circ} \mathrm{C}$ hemen dondurularak incelemeye kadar saklanmıştır.

\section{Biyokimyasal İnceleme}

Alınan kan örnekleri 5 dakika boyunca 4000 rpm' de santrifüj edilerek serumaları alındı. IL-1 $\beta$, IL-6, IL10, Tümör nekerozis faktör (TNF- $\alpha$ ), Malondialdehid (MDA), total antioksidan durum (TAS) ve total oksidan durum (TOS) düzeyleri analiz edildi. Böbrek fonksiyonlarının göstergesi olarak Serum üre azotu (BUN) ve kreatinin ölçümleri otoanalizör ile (Architect c8000, Illinois, ABD) yapıldı. MDA, Esterbauer ve arkadaşlarının ${ }^{10}$ tariflediği şekilde spektrofotometrik olarak bir Shimadzu UV-1201 spektrofotometre (Shimadzu Co., Kyoto, Japonya) ile ölçüldü. Serumun TAS ve TOS değerleri, Erel ${ }^{11}$ tarafından geliştirilen otomatik bir kolorimetrik ölçüm metodu kullanılarak ticari olarak temin edilebilen kitler (Rel Assay,Türkiye) ve Abbott Architect C16000 otoanaliz cihazı (Illinois, ABD) ile ölçülmüsstür. Sonuçlar, TAS ve TOS için sırayla litre başına mikromolar Trolax ( $\mu$ mol Trolax Equiv./L) ve micromolar hidrojenperoksit ( $\mu \mathrm{mol}$ H2O2 Equiv./L) eşdeğeri olarak ifade edildi. IL-1 $\beta$, IL-6, IL10 ve TNF- $\alpha$ 'nın serum aktivitesi, üreticinin talimatlarına göre bir enzime bağlı immünosorbent analiz (ELISA) yöntemi ile belirlenmiştir.

Doku histokimyasal ölçümler için alınan böbrek dokuları gruplara ayrılarak serum fizyolojik ile ylkandıktan sonra $-80{ }^{\circ} \mathrm{C}$ kullanılıncaya kadar saklandı. Tüm örnekleme prosedürleri tamamlandıktan sonra, dokular çözülerek otomatik bir doku homojenleştirici kullanılarak homojenleștirildi. Daha sonra böbrek dokularında TNF- $\alpha$, IL-1 $\beta$, IL-6, IL-10, TAS, TOS ve MDA düzeyleri ölçüldü.

\section{Histopatolojik İnceleme}

Her gruptan alınan böbrek örnekleri, musluk suyunda yıkanıp alkol ile dehidratasyonu sağlandı. Daha sonra ksilen içerisinde temizlenip parafine gömülüp mikrotom kullanılarak 4 micron kalınlığında kesitler alındı. Elde edilen kesitler hematoksilin ve eozin boyası ile boyandı ve sşık mikroskobu kullanılarak incelendi. Tüm preparatlar, çalışma tasarımına ve gruplarına kör olan bir patolog tarafından incelenmiştir. Histopatolojik değerlendirmede kanama, tübüler 
hücre nekrozu, tübüler dilatasyon ve sitoplazmik vaküol oluşumuna bakıldı. Renal yaralanma aşağıdaki şekilde derecelendirildi: Grade 0, Nomal böbrek dokusu, tanısal değişiklik yok; Grade II, tubüler hücresi şişmesi, fırçamsı sınır kaybı, tubuler profilde gürülen $1 / 3$ ve daha az nücleus kaybı; Grade 2, Grade 1'e ek olarak nükleus kaybının 1/3 ile 2/3 arasında olması; Grade 3, nükleus kaybının $2 / 3$ den daha fazla olması.

\section{İstatistiksel Analiz}

Biyokimyasal ve histokimyasal ölçümlerle elde edilen nicel veriler ortalama \pm standart sapma olarak ifade edildi. Verilerin dağılımının normalliği için Komogorov-Smirno testi kullanıldı. Histopatolojik incelemeler sonucu renal hasarın skorlanması ile elde edilen veriler kaydedildi. Gruplar arasında biyokimyasal, histokimyasal ve histopatolojik sonuçlar için çoklu karşılaştırmada Kruskal-Wallis tek yönlü varyans analizi ve ikili grup karşılaştırmasında Mann-Whitney U testleri kullanıldı. $\mathrm{P}<0,05$ değerleri istatistiksel olarak anlamlı kabul edildi.

\section{BULGULAR}

Biyokimyasal ölçümlerde böbrek fonksiyonlarının göstergesi olan Serum BUN ve kreatinin düzeyleri, I/R grubunda Sham grubuna kiyasla yükselmiş ve iskeminin gerçekleştiğini göstermektedir $(p<0.05)$. Ancak I/R grubuna kiyasla I/R +CARV grubunda BUN ve kreatinin düşüş olmakla birlikte fark istatistiksel olarak anlamlı bulunmadı (Şekil 1.) Aynı şekilde I/R grubunda serumda proinflamatuar sitokinlerden IL-6 ve TNF- $\alpha$ ile oksidatif stresin göstergesi olan MDA ve TOS düzeyindeki artış ve anti-inflamatuar sitokin olan IL-10 seviyesinde düşüş istatistiksel olarak anlamlı bulundu $(\mathrm{p}<0.05)$. IR grubunda IL-1 $\beta$ gözlenen artış istatistiksel olarak anlamlı bulunmadı. IR ile IR+CARV grupları karşılaştırıldığında IL-1 $\beta$, IL-6 ve TNF- $\alpha$ değerlerinin CARV verilen grupta düștüğü ve istatistiksel olarak anlamlı olduğu görüldü $(\mathrm{p}<0.05)$. Yine lipid peroksidasyonunun bir ürünü olan MDA'da düşüş izlendi( $\mathrm{p}<0.05)$. Ancak IL-10, TOS ve TAS değerlerinde tedavi grubunda sonuçlar istatistiksel olarak anlamalı bulunmadı (Şekil 2A).
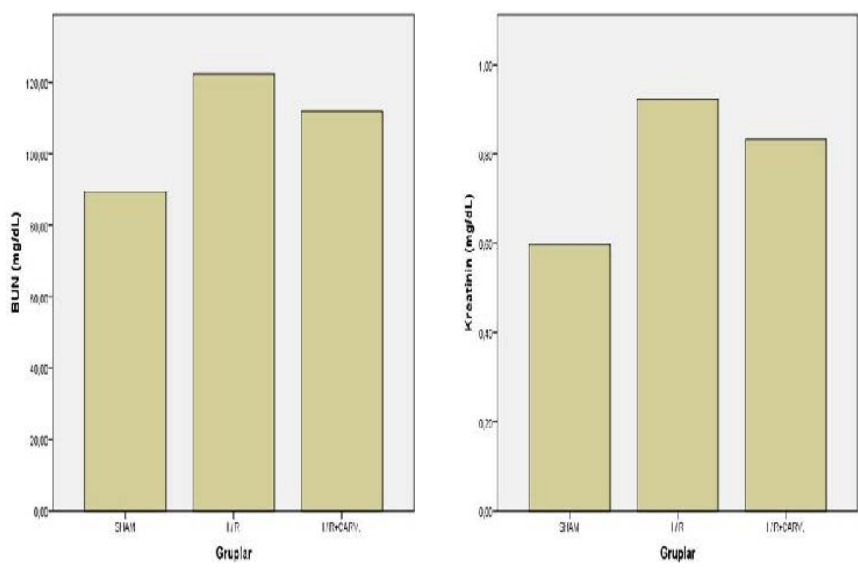

Şekil 1. Sham ve I/R grubları arasında BUN ve Kreatinin değerlerinde anlamlı fark mevcut. I/R+CARV. grubunda düşüş mevcut ancak istatistiksel olarak anlamlı değildi.

Tablo I: Grupların serum biyokimyasal ve doku histokimyasal sonuçları.

\begin{tabular}{|c|c|c|c|c|c|c|c|c|c|c|c|c|c|c|}
\hline & \multicolumn{7}{|c|}{ KAN } & \multicolumn{7}{|c|}{ DOKU } \\
\hline & IL-1 $\beta$ & IL-6 & IL-10 & TNF- $\alpha$ & MDA & $\begin{array}{l}\text { TAS } \\
\text { ( } \mu \text { mTro } \\
\text { lox } \\
\text { equiv./ } \\
\text { L) }\end{array}$ & $\begin{array}{l}\text { TOS } \\
\\
\left(\mu \mathrm{mH}{ }_{2}\right. \\
\mathrm{O}_{2} \\
\text { equiv } \\
\text { /L })\end{array}$ & $\begin{array}{l}\text { IL-1及 } \\
\text { (pg/g } \\
\text { protein) }\end{array}$ & $\begin{array}{l}\text { (pg/g } \\
\text { protei } \\
\text { n) }\end{array}$ & $\begin{array}{l}\text { IL-10 } \\
\text { (pg/g } \\
\text { protei } \\
\text { n) }\end{array}$ & $\begin{array}{l}\text { TNF- } \alpha \\
\text { (ng/g } \\
\text { protei } \\
\text { n) }\end{array}$ & $\begin{array}{l}\text { MDA } \\
\text { ( } \mu \mathrm{M} / \mathrm{g} \\
\text { protei } \\
\mathrm{n})\end{array}$ & $\begin{array}{l}\text { TAS } \\
(\mu \mathrm{mTro} \\
\text { lox } \\
\text { equiv./ } \\
\text { g } \\
\text { protein } \\
)\end{array}$ & $\begin{array}{l}\text { TOS } \\
\left(\mu \mathrm{mH} \mathrm{H}_{2}\right. \\
\mathrm{O}_{2} \\
\text { equiv. } \\
/ \mathrm{g} \\
\text { protei } \\
\mathrm{n})\end{array}$ \\
\hline SHAM & $\begin{array}{l}901 \pm 7 \\
5\end{array}$ & $\begin{array}{l}120 \pm 9 \\
6^{\theta}\end{array}$ & $\begin{array}{l}15 \pm 1 \\
8^{\theta}\end{array}$ & $\begin{array}{l}151 \pm 3 \\
1^{\theta}\end{array}$ & $\begin{array}{l}12 \pm 1 \\
5^{\theta}\end{array}$ & $1,7 \pm 0,1$ & $\begin{array}{l}139 \pm 2 \\
4^{\theta}\end{array}$ & $\begin{array}{l}830 \pm 54 \\
\theta\end{array}$ & $\begin{array}{l}109 \pm 1 \\
5^{\theta}\end{array}$ & $56 \pm 4^{\theta}$ & $134 \pm 8^{\theta}$ & $\begin{array}{l}12 \pm 2 \\
3^{\theta}\end{array}$ & $\begin{array}{l}1,35 \pm 0 \\
3\end{array}$ & $78 \pm 7,{ }^{\theta}$ \\
\hline$I / R$ & $\begin{array}{l}965 \pm 1 \\
06^{*}\end{array}$ & $\begin{array}{l}137 \pm 1 \\
5^{*}, \theta\end{array}$ & $\begin{array}{l}10,5 \pm \\
1^{\theta}\end{array}$ & $\begin{array}{l}173 \pm 1 \\
4^{*}, \theta\end{array}$ & $\begin{array}{l}15 \pm 1 \\
0 * \theta\end{array}$ & $1,5 \pm 0,2$ & $\begin{array}{l}174 \pm 1 \\
0^{\theta}\end{array}$ & $\begin{array}{l}1068 \pm 8 \\
2 *, \theta\end{array}$ & $\begin{array}{l}173 \pm 6 \\
2 *, \theta\end{array}$ & $\begin{array}{l}41 \pm 2^{*} \\
\theta\end{array}$ & $\begin{array}{l}187 \pm 1 \\
1 * \theta\end{array}$ & $\begin{array}{l}19 \pm 1 \\
5^{*, \theta}\end{array}$ & $\begin{array}{l}1,20 \pm 0 \\
4\end{array}$ & $\begin{array}{l}103 \pm 8 \\
* \theta\end{array}$ \\
\hline $\begin{array}{l}I / R+C A \\
R V\end{array}$ & $\begin{array}{l}890 \pm 4 \\
0 *\end{array}$ & $\begin{array}{l}121 \pm 6 \\
8^{*}\end{array}$ & $\begin{array}{l}11 \pm 1 \\
1\end{array}$ & $\begin{array}{l}157 \pm 1 \\
0^{*}\end{array}$ & $\begin{array}{l}13 \pm 0 \\
7^{*}\end{array}$ & $1,6 \pm 0,1$ & $\begin{array}{l}164 \pm 2 \\
4\end{array}$ & $\begin{array}{l}937 \pm 93 \\
*\end{array}$ & $\begin{array}{l}120 \pm 1 \\
1^{*}\end{array}$ & $46 \pm 2^{*}$ & $\begin{array}{l}148 \pm 1 \\
4^{*}\end{array}$ & $\begin{array}{l}16 \pm 1 \\
7 *\end{array}$ & $\begin{array}{l}1,23 \pm 0 \\
2\end{array}$ & $89 \pm 3^{*}$ \\
\hline
\end{tabular}

${ }^{\theta}$ Sham vs. I/R grup ( $\left.p<0.05\right) .{ }^{*} I / R$ vs. I/R+CARV. grup $(p<0.05)$. 

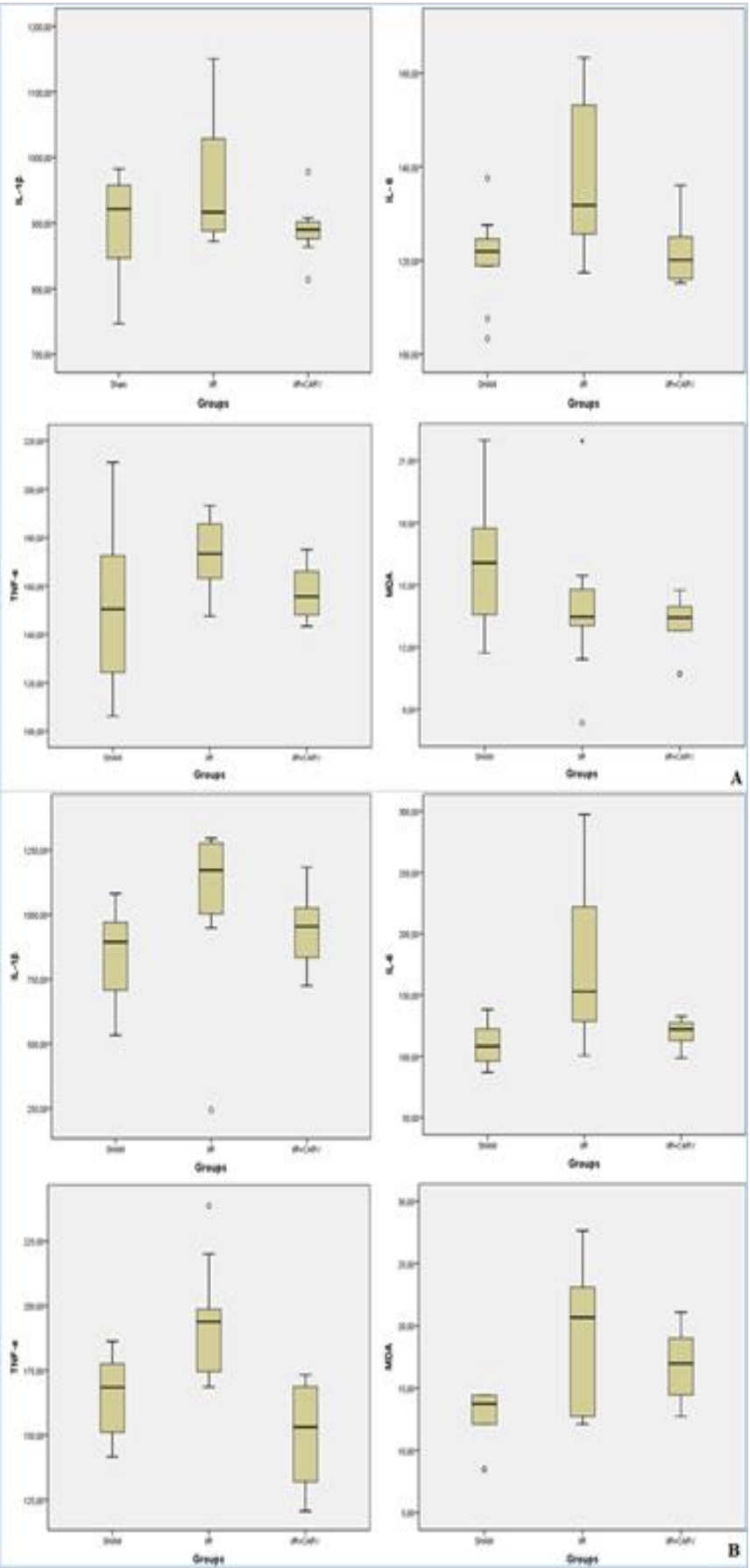

Şekil 2. A. Proinflamatuar sitokinlerin (IL-1 $\beta$, IL-6, TNF$\alpha$ ) ve MDA biyokimyasal değișimleri. B. Proinflamatuar sitokinlerin (IL-1 $\beta$, IL-6, TNF- $\alpha$ ) ve MDA histokimyasal değişimleri.

Histokimyasal ölçümlerde IL-1 $\beta$, IL-6, TNF- $\alpha$, MDA ve TOS değerlerinin Sham grubuna kıyasla I/R grubunda da yükseldiği ve sonuçların istatistiksel olarak anlamlı olduğu görüldü $(\mathrm{p}<0.05)$. Aynı histokimyasal parametrelerde
I/R+CARV grubunda I/R grubuna göre düşüş istatistiksel olarak anlamlı bulundu $(\mathrm{p}<0.05)$. Antiinflamatur sitokin olan IL-10'un I/R+CARV grubunda I/R grubuna göre anlamlı derecede yüksek bulundu(p<0.05)(Şekil 2B.). Tüm biyokimyasal ve histokimyasal sonuçlar Tablo1. de özetlenmiștir.

Histopatolojik incelemede I/R grubunda iskemiye bağlı olarak böbrek tübüllerinde vakuolizasyon ve yer yer nükleus kayıpları olduğu görüldü. I/R+CARV grubunda ise tubüllerde görülen vakuolizasyonun kaybolduğu tespit edildi (Șekil.3).

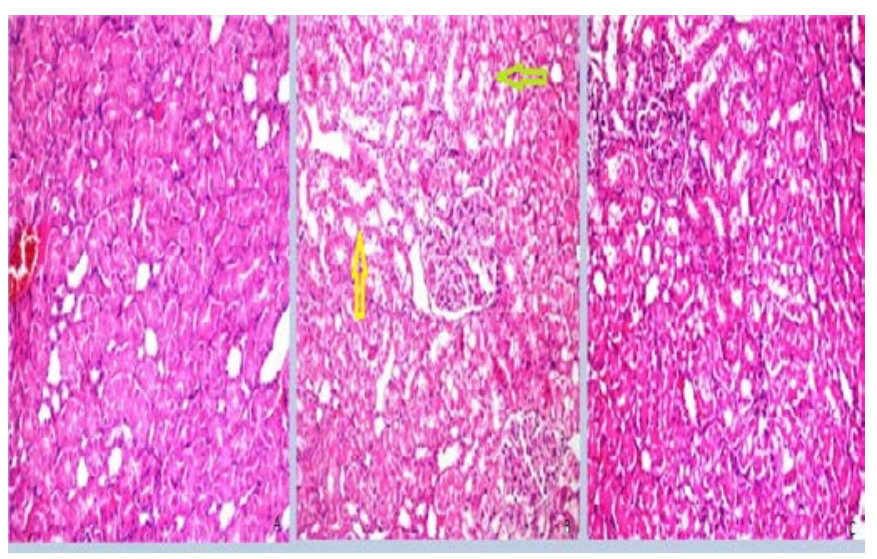

Şekil 3. A. Normal böbrek tübülleri. B. Böbrek tübüllerinde vakuolizasyon (yeşil ok) ve böbrek tübüllerinde nükleus kayıpları (sarı ok) mevcuttur. C. Böbrek tübüllerinde vakuolizasyonda azalma izlenmektedir.(HE;x200)

\section{TARTIŞMA}

İskemi, bir organ veya dokunun normal fizyolojik fonksiyonları korumak ve sürdürmek için gerekli olan oksijen ihtiyacını azaltır. Eğer kısa sürede kan akımı sağlanamaz ise hücre ölümü ve organ disfonksiyonu kaçınılmaz hale gelir. Bununla birlikte kan akımının tekrar sağlanması, reperfüzyon injurisi olarak adlandırılan tabloyla, mevcut durumun daha da ağırlaşmasına yol açmaktadır. Böbrekler, hipoksiye karşı hassas yapıları nedeniyle I/R sırasında etkilenen hayati organlarımızdan birisidir ${ }^{2,12}$. Travma, renovasküler cerrahi, sok, sepsis ve özellikle renal transplantasyon sırasında renal kan akımının durması veya 
azalması, takiben renal kan akımın tekrar başlanması ve oksijenasyonu yukarıda bahsedilen mekanizmayla ABH'na yol açmaktadır ${ }^{13}$. Özellikle renal transplantasyon esnasında greftin maruz kaldığı soğuk iskemi ve reperfüzyon, greft disfonksiyonuna ve rezeksiyonuna yol açarak ölüme kadar giden ciddi komplikasyonlara sebep olabilmektedir4 .

İnflamasyon, IRH'da rol oynayan önemli patofizyolojik süreçlerden birisidir ${ }^{6,14,15}$. Iflamatuar yanita cevap olarak makrofaj ve monositlerlerden proinflamatuar sitokinler salınmaya başlar. Akabinde anti-inflamatuar etkiye sahip olan IL-10, IL-4 gibi sitokinler salınarak inflamatuar etkiye sahip olan stokinlerin(IL-1 $\beta$, IL-6, TNF- $\alpha$, ) salınımını baskılamaktadır ${ }^{16}$. Yapılan çalışmalarda IRH'da proinflamatuar sitokinlerin arttığ gösterilmiştir ${ }^{17}$. Nötrofillerin aktivasyonu ile birlikte pro-inflamatuar sitokinler ve kemokinler üretilmeye başlanmaktadır ${ }^{18,19}$. Bu nedenle inflamasyon, IRH'nı azaltmak için yeni ilaç tedavilerinin geliştirilmesinde bir hedef haline gelmiştir7,20-23. Bu amaçla, anti inflamatuar, antioksidan, sitoprotektif, antitümöral ve antimikrobial özelliğe sahip olduğu bildirlien CARV, renal IRH'nın önlenmesinde koruyucu rol oynayabilir. CARV'un bilateral renal IRH'da antioksidan, antiinlamatuar ve sitoprotektif mekanizmalarla koruyucu etkiye sahip olabileceği bildirilmiştir ${ }^{3}$. Lima ve arkadaşlarının ${ }^{9}$ yaptığı bir başka çalışmada Carvacrol'un anti-inflamatuar etkisini proinflamatuar sitokinlerin salınımını baskllayarak ve anti- inflamatuar bir sitokin olan IL-10 salınımını arttırarak sağladığını bildirmişlerdir. Çalıșmamızda da I/R grubunda Sham grubuna kıyasla proinflamatuar stokinler olan TNF- $\alpha$, IL-1 $\beta$ ve IL-6'nın arttığ ve antiinflamatuar etkiye sahip olan IL-10'un düştüğü görülmüştür $\quad(\mathrm{p}<0.05)$. CARV uygulanan grupta ise TNF- $\alpha$, IL-1 $\beta$ ve IL- 6 düșerken $\quad(p<0.05), \quad$ inflamasyonun önlenmesinde hayati bir öneme sahip olan IL-
$10^{24}$ düzeyinin özellikler doku biokimyasında arttığı tespit edilmiştir. Ancak serum IL-10 düzeyi I/R+CARV grubunda yükselmesine rağmen fark istatistiksel olarak anlamlı bulunmadı. IL-10 düzeyi maksimum seviyeye inflamasyonun 24-48. saatlerde ulaștığ bildirilmektedir ${ }^{25}$. Çalışmamızda iskemi ve reperfüzyon süresi toplamda 7 saat olup, beklenilen artışın süreye bağlı olarak gerçekleşmemiş olabileceğini düşünmekteyiz.

Fizyoloji şartlarda kontrollü bir şekilde SOR ve antioksidanlar üretilir. Doku bütünlügünün ve fonksiyonlarının normal düzeylerde sürdürülmesi için üretilen SOR'lar, endojen glutatyon (GSH), glutatyon peroksidaz (GPO), glutatyon reduktaz (GRx), glutatyon $s$ transferaz (GST), süperoksid dismutaz (SOD), katalaz (CAT) ve diğer antioksidan (A,C, E vitaminler) savunma sistemlerince nötralize edilirler ${ }^{26}$. SOR, direkt endoteliyal hasara neden olduğu gibi iskemik dokularda nötrofil infiltrasyonuna neden olarak oksidatif hasarı daha da arttırmaktadır. SOR oluşumunun artması ve detoksifikasyon kabiliyetinin üzerine çıkmasıyla membran lipidleri, protein ve nükleik asid gibi makromoleküller üzerine olumsuz etkilere yol açmaktadır ${ }^{3,8}$. Önceki çalşmalarda oksidatif stres göstergesi olarak oksidatif ve antioksidatif bazı parametreler üzerinde biyodoku biyokimyasal ölçümlerde Sham grubuyla kiyaslandığında I/R grubunda TOS değerlerinin anlamlı bir şekilde yükseldiği görülmesine rağmen tüm grupların serum ve doku analizlerinde TAS seviyesinde, gruplar arasında anlamlı fark gözlenmemiştir. I/R+CARV grubunda ise doku düzeyinde TOS'un anlamlı bir şekilde düștüğü ancak serum değerlerinde düşüş olmakla birlikte anlamlı fark bulunmadı.

SOR membran lipidleri ile çift bağ yapar ve lipidradikal etkileşimi ile zincirleme reaksiyon sonucu pek çok lipid peroksidasyon ürünü (malondialdehit, dien konjugatları gibi) oluşur. Lipid peroksidasyonu membran yapısına zarar 
vererek membran geçirgenliğini bozar ve akışkanlığını etkiler ${ }^{29}$. OH ve 02 - radikali lipid peroksidasyonuna neden olan en önemli etken maddedir. Serbest radikal doymamış yağ asidinin bir metilen karbonuna bağlı bir $\mathrm{H}$ atomunu yerinden çıkartır ve lipid radikali oluşur. Lipid peroksidasyonun ürünü ve oksidatif stresin indirekt göstergesi olan MDA, bakılan doku biokimyasında I/R grubunda, sham grubuna kiyasla yükselmiştir. I/R grubunda iskemi ve buna bağlı oksidatif stresin arttığını göstermektedir. I/R+CARV grubunda MDA hem serum hemde doku biokimyasında anlamlı derecede düştüğü görülmüştür $(\mathrm{P}<0,05)$. Buda CARV'un lipid peroksidasyonunu önlediğini göstermektedir.

Öztürk ve arkadaşlarının² ratlarda bilateral I/R modelinde CARV'un renal fonsiyonlar üzerine de olumlu etkisinin oluştuğunu bildirmektedir. Carcavrol uygulanan grupta I/R grubuna göre 24. saatte bakılan BUN ve kreatinin değerlerinin düştüğü bildirilmiştir. Çalışmamızda da I/R grubunda BUN ve kreatinin düzeyinin Sham grubuna göre yükseldiği görüldü $(\mathrm{P}<0,05)$. Ancak tedavi grubunda ki düşüş istatistiksel olarak anlamlı bulunmadı. Bunun reperfüzyon süresinin kısa olmasından kaynaklanmış olabileceğini düşünmekteyiz.

Histopatolojik incelemede I/R grubunda renal tübüllerinde vakuolizasyon ve nükleus kayıpları gözlenirken, tedavi grubunda vakuolizasyonun ve nükleus kayıplarının azaldığı gösterilmiştir.

Sonuç olarak Carvacrol'un, ratlarda renal I/R ile indüklenen renal hasar üzerinde proinflamatuar sitokinlerin salınımı baskılayarak ve antiiflamatuar sitokin olan IL10 salınımı arttırarak renal yapı ve fonksiyon üzerinde olumlu etkiye sahip olduğu görülmektedir. Antioksidan parametreler üzerinde de olumlu etkilere sahip olmasına rağmen, antiinflamatur etkinliğinin daha ön planda olduğu gözlendi. Düşük antioksidan etki CARV'un dozuna ve reperfüzyon süresinin kısa oluşuna bağlı olabilir. Bu nedenle CARV'un doz ve organın reperfüzyon süresine bağlı etkilerinin ortaya konulması için daha kapsamlı çalışmalara ihtiyaç duyulmaktadır.

Etik Kurul Kararı: Dicle Üniversitesi Hayvan Deneyleri Yerel Etik Kurulu onayı (13.05.2014/3) alındı.

Çıkar Çatışması Beyanı: Yazarlar çıkar çatışması olmadığını bildirmişlerdir.

Finansal Destek: Bu çalışma her hangi bir fon tarafından desteklenmemiştir.

Declaration of Conflicting Interests: The authors declare that they have no conflict of interest.

Financial Disclosure: No financial support was received.

\section{KAYNAKLAR}

1. Himmelfarb J, Ikizler TA. Acute kidney injury: Changing lexicography, definitions, and epidemiology. Kidney Int. 2007; 71: 971-6.

2. Kara AV, Tanrikulu S, Aydın E, et al. Evaluation of the effect of red cell distribution width on the development of acute renal failure in patients with sepsis. Dicle Med J. 2017; 44: 191-8

3. Ozturk H, Cetinkaya A, Duzcu SE, et al. Carvacrol attenuates histopathogic and functional impairments induced by bilateral renal ischemia/reperfusion in rats. Biomed Pharmacother. 2018; 98: 656-61.

4. Salvadori M, Rosso G, Bertoni E. Update on ischemia-reperfusion injury in kidney transplantation: Pathogenesis and treatment. World J Transplant. 2015; 5: 52-67.

5. Weight SC, Bell PR, Nicholson ML. Renal ischaemia-reperfusion injury. Br J Surg. 1996; 83: 162-70.

6. Hong X, Zhao X, Wang G, et al. Luteolin treatment protects against renal ischemia-reperfusion injury in rats. Mediators Inflamm. 2017; 2017: 9783893.

7. Cho JH, Choi SY, Ryu HM, et al. Fimasartan attenuates renal ischemia-reperfusion injury by modulating inflammation-related apoptosis. Korean J Physiol Pharmacol. 2018; 22: 661-70. 
8. Akdere $\mathrm{H}$, Tastekin $\mathrm{E}$, Mericliler $\mathrm{M}$, et al. The protective effects of Ginkgo biloba EGb761 extract against renal ischemia-reperfusion injury in rats. Eur Rev Med Pharmacol Sci. 2014; 18: 2936-41.

9. Lima Mda S, Quintans-Junior LJ, de Santana WA, et al. Anti-inflammatory effects of carvacrol: evidence for a key role of interleukin-10. Eur J Pharmacol. 2013; 699: 112-17.

10. Esterbauer $\mathrm{H}$, Zollner $\mathrm{H}$. Methods for determination of aldehydic lipid peroxidation products. Free Radic Biol Med. 1989; 7: 197-203.

11. Erel O. A new automated colorimetric method for measuring total oxidant status. Clin Biochem. 2005; 38: 1103-11.

12. Chatterjee PK. Novel pharmacological approaches to the treatment of renal ischemiareperfusion injury: a comprehensive review. Naunyn Schmiedebergs Arch Pharmacol. 2007; 376: $1-43$.

13. Kellum JA, Unruh ML, Murugan R. Acute kidney injury. BMJ Clin Evid. 2011; 28: 2001.

14. Malek M, Nematbakhsh M. Renal ischemia/reperfusion injury; from pathophysiology to treatment. J Renal Inj Prev. 2015; 4: 20-7.

15. Edelstein CL. Biomarkers of acute kidney injury. Adv Chronic Kidney Dis. 2008; 15: 222-34.

16. Hopkins SJ. The pathophysiological role of cytokines. Leg Med. 2003; 5: 45-57.

17. Kinsey GR, Li L, Okusa MD. Inflammation in acute kidney injury. Nephron Exp Nephrol. 2008; 109: 102-7.

18. Bonventre JV, Weinberg JM. Recent advances in the pathophysiology of ischemic acute renal failure. J Am Soc Nephrol. 2003; 14: 2199-210.

19. Bonventre JV, Zuk A. Ischemic acute renal failure: An inflammatory disease? Kidney Int. 2004; 66: 4805.
20. Rah DK, Han DW, Baek HS, et al. Protection of rabbit kidney from ischemia/reperfusion injury by green tea polyphenol pretreatment. Arch Pharm Res. 2007; 30: 1447-54.

21. Korkmaz A, Kolankaya D. The protective effects of ascorbic acid against renal ischemia-reperfusion injury in male rats. Ren Fail 2009; 31: 36-43.

22. Kontogiannis J, Burns KD. Role of AT1 angiotensin II receptors in renal ischemic injury. Am J Physiol. 1998; 274: 79-90.

23. Choucry MA, Khalil MNA, El Awdan SA. Protective action of Crateva nurvala Buch. Ham extracts against renal ischaemia reperfusion injury in rats via antioxidant and anti-inflammatory activities. J Ethnopharmacol. 2018; 214: 47-57.

24. Iyer SS, Cheng G. Role of interleukin 10 transcriptional regulation in inflammation and autoimmune disease. Crit Rev Immunol. 2012; 32: 23-63.

25. de Waal Malefyt R, Abrams J, Bennett B, et al. Interleukin 10 (IL-10) inhibits cytokine synthesis by human monocytes: an autoregulatory role of IL-10 produced by monocytes. J Exp Med. 1991; 174: 1209-20.

26. Urso ML, Clarkson PM. Oxidative stress, exercise, and antioxidant supplementation. Toxicology. 2003; 189: 41-54.

27. Okur MH, Arslan S, Aydogdu B, et al. Protective effect of cordycepin on experimental testicular ischemia / reperfusion injury in rats. J Invest Surg. 2018; 31: 1-8.

28. Gokce A, Oktar S, Koc A, et al. Protective effect of thymoquinone in experimental testicular torsion. Urol Int. 2010; 85: 461-5.

29. Ates M, Köksal MH, Celayir MF, et al. Prophylactic and therapeutic effect of ginko biloba extract (Egb761) on mortality of intestinal deep ischemiareperfusion model in rats. Dicle Med J. 2010; 37: 199-203. 